\title{
Evapotranspiration, water use efficiency and crop coefficient of three lettuce varieties grown in a tropical region
}

\section{Evapotranspiração, eficiência do uso de água e coeficiente de cultivo de três variedades de alface cultivadas em região tropical}

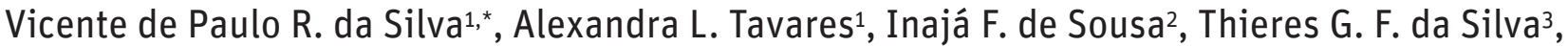 \\ Romildo M. de Holanda ${ }^{3}$, Enio P. de Souza ${ }^{1}$, Bernardo B. da Silva ${ }^{1}$, Célia C. Braga ${ }^{1}$ \\ and Rafaela S. R. Almeida ${ }^{1}$
}

\author{
${ }^{1}$ Federal University of Campina Grande, Av. Aprígio Veloso, 882, Bodocongó, 58109 970, Campina Grande, PB, Brazil \\ ${ }^{3}$ Federal University of Sergipe, Avenida Marechal Rondon, S/n - Jardim Rosa Elze, São Cristóvão - SE, 49100-000, Brazil \\ 2 Federal Rural University of Pernambuco, R. Manuel de Medeiros, S/N - Dois Irmãos, Recife - PE, 52171-900, Brazil \\ ( ${ }^{*}$-mail: vicente@dca.ufcc.edu.br) \\ http://dx.doi.org/10.19084/RCA18042
}

Received/recebido: 2018.02.16

Received in revised form/recebido em versão revista: 2018.05 .10

Accepted/aceite: 2018.06.02

\begin{abstract}
A B S T R A C T
Three field experiments were carried out in a tropical environment in Brazil in order to evaluate the effect of planting date on crop evapotranspiration $\left(\mathrm{ET}_{\mathrm{c}}\right)$, crop coefficient $\left(\mathrm{K}_{\mathrm{c}}\right)$ and water use efficiency (WUE) of three lettuce (Lactuca sativa L.) cultivars grown in different seasons (autumn, winter and summer) under tropical climate. $\mathrm{ET}_{\mathrm{c}}$ values were obtained through the soil water balance method and reference evapotranspiration $\left(\mathrm{ET}_{\mathrm{o}}\right)$ through the Penman-Monteith method, using data collected in an automatic weather station located close to the experimental area. The results of the research showed that the mean values of $\mathrm{ET}_{\mathrm{c}}$ and $\mathrm{K}_{\mathrm{c}}$ for lettuce were $3.5 \mathrm{~mm}$ day-1 and 0.82 , respectively. The curly cultivar showed the highest yield $\left(40.8 \mathrm{~kg} \mathrm{ha}^{-1}\right)$ during the autumn transplanting date. Results also showed that the three lettuce varieties have different responses to the climatic conditions. The greatest WUE was observed for the three lettuce varieties when they were grown during the autumn growing season, and the lowest values occurred during the winter growing season.
\end{abstract}

Keywords: Lactuca sativa L; Soil water moisture; Water balance.

\section{R E S U M O}

Três experimentos de campo foram conduzidos em ambiente tropical no Brasil com o objetivo de avaliar os efeitos da data de plantio sobre a evapotranspiração $\left(\mathrm{ET}_{\mathrm{c}}\right)$, o coeficiente de cultivo $\left(\mathrm{K}_{\mathrm{c}}\right)$ e eficiência de uso da água (EUA) de três variedades de alface (Lactuca sativa L.). A cultura foi cultivada em diferentes épocas do ano (outono, inverno e verão) sob clima tropical. Os valores de $\mathrm{ET}_{\mathrm{c}}$ foram obtidos através do método do balanço hídrico do solo e a evapotranspiração de referência $\left(\mathrm{ET}_{\mathrm{o}}\right)$ pelo método de Penman-Monteith, utilizando dados coletados em uma estação meteorológica automática localizada próxima à área experimental. Os resultados da pesquisa mostraram que os valores médios de $\mathrm{ET}_{\mathrm{c}}$ e $\mathrm{K}_{\mathrm{c}}$ do alface foram 3,5 mm dia $\mathrm{m}^{-1}$ e 0,82, respectivamente. A variedade crespa apresentou a maior produtividade $\left(40,8 \mathrm{~kg} \mathrm{ha}^{-1}\right)$ durante o plantio de outono. Os resultados também evidenciaram que as três variedades de alface têm respostas diferentes às condições climáticas da região. A maior EUA das três variedades de alface ocorreram quando elas foram cultivadas durante a estação o outono e os valores mais baixos ocorreram durante o cultivo de inverno.

Palavras-chave: Lactuca sativa L; Humidade do solo; Balanço hídrico. 


\section{INTRODUCTION}

Climatic variability affects quantity and quality of water resources, especially in regions with low rainfall. The great challenge for the next decades will be to increase food production with less water, in order to guarantee the food supply worldwide. The need for quantifying water consumption of agricultural crops for the dimensioning of irrigated agriculture has stimulated various studies in many parts of the world (Azevedo et al., 2003; Allen et al., 2005; Silva et al., 2009, 2013; Ghiberto et al., 2011; FernándezPacheco et al., 2014; Pereira et al., 2015). The knowledge on the precise values of the crop coefficient $\left(\mathrm{K}_{\mathrm{c}}\right)$ is particularly important for the determination of the water requirements of the crops, in terms of both irrigation water management and planning of hydro-agricultural systems. Therefore, it is essential to determine the water consumption of various types of crops under the edaphoclimatic conditions of their cultivation areas, with sustainable use of the water resources (Azevedo et al., 2003; Silva et al., 2009, 2013; Bezerra Neto et al., 2012).

Lettuce is the most cultivated vegetable in Brazil (Cometti et al., 2011) and the most important crop in the group of leafy vegetables (Krrístková et al., 2008). This crop also is the leafy vegetable most consumed in Brazil, making up approximately $40 \%$ of the total volume traded in fresh produce supply companies (Sala and Costa, 2012) with the cultivar iceberg as the most widely consumed in the country (Oliveira et al., 2010). Diverse landraces and local varieties are cultivated in different regions with a broad spectrum of landraces (Kř́stková et al., 2008). However, lettuce cultivation under high temperatures becomes susceptible to the incidence of diseases and occurrence of nutritional imbalance in the plants, especially in the Brazilian summer, characterized by rainy days with high temperatures (Ceuppens et al., 2014). Curly and looseleaf lettuce varieties are the most known and consumed in Brazil. They were genetically improved for summer cultivation or adapted to tropical regions, with high temperatures and rainfall; however, in the last years, cultivars with a purple color and jagged leaves also appeared. So, the present study aims to determine evapotranspiration, crop coefficients and water use efficiency of three lettuce cultivars along their production cycles in a tropical region.

\section{MATERIAL AND METHODS}

Field experiments were carried out over three successive seasons in 2013 and 2014 at the Vegetable Production Unit, belonging to the company Hortaliças Vida Verde, in partnership with the Federal University of Sergipe (UFS),

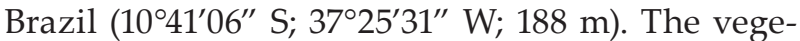
table cultivation area belonging to this enterprise comprehends approximately 6.5 hectares. The climate is characterized as tropical, with mean annual temperature of $24.5^{\circ} \mathrm{C}$, annual evaporation of $1,850 \mathrm{~mm}$, mean relative humidity of $60 \%$ and mean rainfall of $839 \mathrm{~mm}$. The rainy period occurs between May and July (Silva, 2004).

The soil in the experimental area is classified as Red Yellow Argisol, with sandy loam texture, as sand at $0-15 \mathrm{~cm}$ depth and as loam at $15-30 \mathrm{~cm}$. The soil chemical composition indicated mean contents of potassium, calcium and magnesium of $87.3 \mathrm{mg} / \mathrm{dm}^{3}, 50 \mathrm{mg} / \mathrm{dm}^{3}$ and $2.9 \mathrm{cmol} / \mathrm{dm}^{3}$, respectively (Table 1). The daily meteorological data for determining $\mathrm{ET}_{\mathrm{o}}$ were obtained from the automatic weather station located $600 \mathrm{~m}$ from the experimental area.

The studied crop was lettuce (Lactuca sativa L.), planted at spacing of $0.40 \mathrm{~m}$ between rows and $0.40 \mathrm{~m}$ between plants, totaling 80 plants per experimental plot for each cultivar. The lettuce crop was initially sown on polyethylene trays, maintained in protected cultivation and irrigated through micro-sprinklers. The plots were subdivided into three rows (beds) corresponding to each lettuce cultivar: Looseleaf (Saia Véia), Curly (Isabela) and

Table 1 - Physical and chemical characteristics of the soil in the experimental area

\begin{tabular}{lllll}
\hline \multicolumn{5}{c}{ Physical characteristics } \\
\hline Soil depth $(\mathrm{cm})$ & \multicolumn{5}{c}{ Soil granulometry $(\%)$} \\
\hline & Sand & Silt & Loan & Soil Texture \\
$0-15$ & 80.0 & 13.0 & 7.0 & Sand \\
$15-30$ & 26.0 & 36.0 & 38.0 & Loan \\
\hline \multicolumn{5}{c}{ Chemical characteristics } \\
\hline $\mathrm{pH}\left(\mathrm{H}_{2} \mathrm{O}\right)$ & 7.7 & $\mathrm{Mg}\left(\mathrm{cmol} / \mathrm{dm}^{3}\right)$ & -2.9 \\
$\mathrm{MO}\left(\mathrm{dag} / \mathrm{cm}^{3}\right)$ & -0.6 & $\mathrm{Al}\left(\mathrm{cmol} / \mathrm{dm}^{3}\right)$ & 0.0 \\
$\mathrm{P}\left(\mathrm{mg} / \mathrm{dm}^{3}\right)$ & -87.3 & $\mathrm{H}+\mathrm{A} 1\left(\mathrm{cmol} / \mathrm{dm}^{3}\right)$ & -0.7 \\
$\mathrm{~K}\left(\mathrm{mg} / \mathrm{dm}^{3}\right)$ & -50 & $\mathrm{CTN}\left(\mathrm{cmol} / \mathrm{dm}^{3}\right)$ & -5.6 \\
$\mathrm{Ca}\left(\mathrm{mg} / \mathrm{dm}^{3}\right)$ & 1.9 & $\mathrm{~V}(\%)$ & 87.8 \\
\hline
\end{tabular}


Red (Rouge). The planting density in the experimental area was 125,000 plants/ha. The study was conducted with three replicates in different periods of the year: winter, summer and autumn. A micro-sprinkler irrigation system was used and the flow rate of the irrigation pipe was equal to $60 \mathrm{~L} \mathrm{~h}^{-1}$. Irrigations were performed twice a day, according to the $\mathrm{ET}_{\mathrm{o}}$. For each experimental plot of $15.0 \mathrm{~m} \times 0.7 \mathrm{~m}, 5$ access tubes were installed to measure soil water content in three replicates for each lettuce cultivar (Figure 1). The field experiments were performed in different periods; the first, second and third campaigns were conducted in the winter, summer and autumn seasons, respectively.

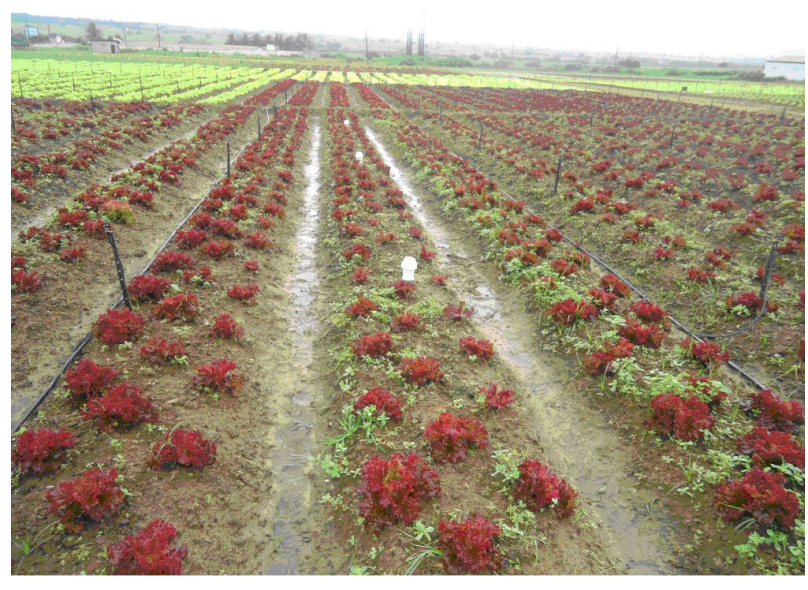

Figure 1 - Field plot layout showing experimental design with 5 access tubes.

Soil water content was measured using a portable soil moisture monitoring system (Diviner 2000, Sentek Pty. Ltd., Australia) previously calibrated for the soil of the experimental area with the gravimetric sampling technique, according to Groves and Rose (2004). The Diviner 2000 is a portable soil moisture monitoring instrument that consists of a probe and hand-held data logger (Zhou et al., 2008). Five access tubes were installed in the plot (Figure 1). The measurements of mean volumetric soil water content were performed at daily intervals after each irrigation or rainfall at every $10 \mathrm{~cm}$ of depth from the surface down to $50 \mathrm{~cm}$ depth. Irrigation management was performed using the crop coefficient established in the FAO-56 Bulletin (Allen et al., 1998).
Crop evapotranspiration (ET) was determined through the soil water balance method, as follows:

$E T_{c}=P+I+A-D-\Delta W \pm R$

where P - rainfall; I - irrigation depth; A - capillary rise; $\mathrm{D}$ - deep drainage; $\Delta \mathrm{W}$ - variation of water depth available in the soil and $\mathrm{R}$ - surface runoff. All the components of Eq. (1) are expressed in $\mathrm{mm}$. Rainfall was monitored using a pluviometer, installed in the experimental area, and $\Delta \mathrm{W}$ was determined based on the soil moisture profile. The control volume considered for the water balance corresponds to the soil layer between the surface and the effective root system depth $(0.4 \mathrm{~m})$. Since the water table in the studied area is more than $1 \mathrm{~m}$ deep, the term capillary rise was considered as null. Soil water drainage was obtained based on the procedures established by Azevedo et al. (2006).

Surface runoff (R) was not considered because the topography of the terrain is flat. The values in $\mathrm{ET}_{\mathrm{o}}$ were determined using the air temperature, net radiation, wind speed and relative humidity data and the FAO Penman-Monteith equation (Allen et al., 1998). The crop coefficient was determined through the ratio between $\mathrm{ET}_{\mathrm{c}}$ and $\mathrm{ET}_{\mathrm{o}}$ defined by meteorological data. On other hand, WUE was obtained as the ratio between grain weight or biomass yield and crop evapotranspiration expressed in units of kilograms per hectare per millimeter of water (Zhang et al., 2004).

\section{RESULTS AND DISCUSSION}

Thetotal rainfallduring thefirstexperimentalperiod was higher compared with the others, $197.2 \mathrm{~mm}$; however, the summer showed the lowest total rainfall, representing only $24 \%$ of the total in the winter. The highest values of insolation and evaporation occurred in the summer, but the total insolation in the winter represented $74 \%$ of that in the summer and $90 \%$ of that in the autumn. Temperatures did not vary much between the seasons and the mean values in the summer and autumn were virtually equal, around $27^{\circ} \mathrm{C}$, representing only $10 \%$ of the mean temperature of the first experiment, during the winter. 
Relative humidity also varied substantially between the summer and autumn seasons in the studied area. Summer transplanting date was the warmest, followed by the autumn and winter seasons and insolation was quite high during all seasons. The highest insolation and Class A pan evaporation values were recorded during the summer season. Temperatures did not vary much between the seasons and the mean values of summer and autumn were virtually equal, around $27^{\circ} \mathrm{C}$, representing only $10 \%$ of the mean temperature of the first experimental campaign, during the winter. Mean annual relative humidity varied significantly between the seasons, from $39 \pm 5.4 \%$ in the spring growing season to $56 \pm 12.5 \%$ in the autumn season.

The highest values of lettuce yield occurs during autumn growing season, ranged from 22.1 to 40.7 $\mathrm{T} \mathrm{ha}^{-1}$ (Table 2). A similar result was obtained by Candido et al. (2011) when analyzing lettuce yield response under field and greenhouse conditions in Southern Italy. They found lettuce yield ranging from 33.6 $\mathrm{T} \mathrm{ha}^{-1}$ to $43.2 \mathrm{~T} \mathrm{ha}^{-1}$, according to treatment type. Earlier, Hanson et al. (1997) also reported lettuce yield ranging from $30.6 \mathrm{~T} \mathrm{ha}^{-1}$ to $40.9 \mathrm{~T} \mathrm{ha}^{-1}$ on a farm in the Salinas Valley of California.

The curly cultivar showed the highest yield during the growing season for the autumn transplanting date with highest maximum temperature and insolation quite high. When analyzing the dynamic relationships between field temperatures and Romaine lettuce yield in South Carolina, USA, Dufault et al. (2009) observed a linear increase in some varieties of lettuce when temperature increased. On the other hand, the lowest value of lettuce yield was found in the summer growing season with the red cultivar,

Table $\mathbf{2}$ - Yield of the three lettuce varieties during the winter, summer and autumn seasons in Brazil

\begin{tabular}{lccc}
\hline \multirow{2}{*}{ Variety } & \multicolumn{3}{c}{ Yield $\left(\mathrm{T} \mathrm{ha}^{-1}\right)$} \\
\cline { 2 - 4 } & Winter & Summer & Autumn \\
\hline Looseleaf & $11.6 \mathrm{bB}$ & $18.5 \mathrm{aA}$ & $22.1 \mathrm{bA}$ \\
Curly & $19.7 \mathrm{aB}$ & $13.4 \mathrm{aC}$ & $40.7 \mathrm{aA}$ \\
Red & $8.0 \mathrm{bB}$ & $7.5 \mathrm{bB}$ & $27.1 \mathrm{bA}$ \\
\hline
\end{tabular}

Means followed by the same letters, uppercase in rows and lowercase in columns, do not differ by the Tukey's test ( $\mathrm{s} 0.05)$. followed by the looseleaf cultivar. Some studies have indicated high temperatures as limiting factor for lettuce production with accelerated inflorescence formation and shortened vegetative period in the plants (Ryder, 1986; Sala and Costa, 2012).

There were significant differences between varieties and growing seasons, ranging from minimum value of $7.5 \mathrm{~T} \mathrm{ha}^{-1}$ for red/summer to $40.7 \mathrm{~T} \mathrm{ha}^{-1}$ for curly/autumn. A reduction in the yield of the curly cultivar grown during autumn was found to be $32.9 \%$ compared with that in the summer growing season, in part due to high values of both air temperature and insolation. The three lettuce varieties showed similar yield during the winter and autumn growing seasons; however, the yield values of the three lettuce varieties during summer growing season are statistically different by Tukey's test $(p \leq 0.05)$. On the other hand, the looseleaf cultivar showed higher yield in the summer, also statistically different from the others. The red cultivar reached the lowest values of leaf fresh weight production and, during the autumn season, its yield was not statistically different from that of the looseleaf cultivar. The results of the current study also indicate that the autumn cultivation lead significant increase in lettuce yield.

All analyzed growth variables of the lettuce crop showed higher development in the autumn period, although it was not the rainiest period in the studied area. The total rainfall in the autumn was $38.5 \%$ of that recorded in the winter. This result is partially contrary to that obtained by Serna et al. (2012), who observed high yield caused by an increase in lettuce weight (which causes diameter and length increases) caused by an increment of water absorption. On the other hand, Galieni et al. (2015) analyzed the effects of nutrient deficiency and abiotic environmental stresses on lettuce yield and found high values of yield, leaf number and leaf length in unstressed plants. The results of the present study clearly demonstrate the decrease in the yield of the red cultivar during the winter growing season.

There were no significant differences in mean daily $\mathrm{ET}_{\mathrm{c}}$ between the three lettuce varieties (Table 3). Otherwise, there were significant differences for $\mathrm{ET}_{\mathrm{c}}$ values between growing seasons. In this aspect, the lettuce crop shows higher evapotranspiration in the summer, followed by the periods 
Table 3 - Analysis of variance of the mean values of evapotranspiration for the three lettuce varieties during the three experimental campaigns (winter, summer and autumn)

\begin{tabular}{lllll}
\hline \multirow{2}{*}{ Variety } & \multicolumn{4}{c}{ Evapotranspiration (mm/day) } \\
\cline { 2 - 5 } & Looseleaf & Curly & Red \\
\hline Winter & $2.74 \mathrm{bA}$ & $2.67 \mathrm{bA}$ & $2.69 \mathrm{bA}$ \\
Summer & $4.55 \mathrm{aA}$ & $4.53 \mathrm{aA}$ & $4.78 \mathrm{aA}$ \\
Autumn & $3.07 \mathrm{abA}$ & $3.10 \mathrm{abA}$ & $3.05 \mathrm{bA}$ \\
\hline
\end{tabular}

Means followed by the same letters, uppercase in rows and lowercase in columns, do not differ by the Tukey's test $(p \leq 0.05)$

of autumn and winter. For each growing season, no significant differences in evapotranspiration values were found between varieties. Therefore, since the $\mathrm{ET}_{\mathrm{c}}$ did not show significant statistical differences between the varieties, this figure was made based on the mean values of $\mathrm{ET}_{\mathrm{c}}$ of the three varieties.

In the first experimental campaign (Figure 2A), during the winter, when there were higher rainfalls (total of $197.2 \mathrm{~mm}$ ), the mean evapotranspiration was $1.75 \mathrm{~mm}$, reaching maximum value of $4.29 \mathrm{~mm}$ at 21 DAT. In the second experimental campaign (Figure 2B), for being the summer growing season, with total rainfall of $48.0 \mathrm{~mm}$ and irrigation prevailed, with maximum values at 14 and 21 DAT of $39.5 \mathrm{~mm}$. These results confirm that the plant responded to the increase in soil moisture, because the maximum value of $\mathrm{ET}_{\mathrm{c}}$ of $6.30 \mathrm{~mm}$ occurred at 21 DAT and minimum of $4.02 \mathrm{~mm}$ at 28 DAT. In the third experimental campaign, during autumn, the highest cumulative values of rainfall occurred at the beginning and end of the lettuce cycle, with $51.7 \mathrm{~mm}$ (7 DAT) and $56.2 \mathrm{~mm}$ (42 DAT), respectively, with maximum peak of $\mathrm{ET}_{\mathrm{c}}$ of $4.92 \mathrm{~mm}$ at $21 \mathrm{DAT}$, and minimum of $1.02 \mathrm{~mm}$ at 42 DAT.

Crop water requirements are higher in the summer period, reaching $208.08 \mathrm{~mm}$ (Table 4). In winter, since the atmospheric demand was lower, the $\mathrm{ET}_{\mathrm{c}}$ was $66 \%$ lower than that in the summer growing season. As a result, the values of crop coefficients for winter, summer and autumn growing seasons were $0.71,1.04$ and 0.72 , respectively.
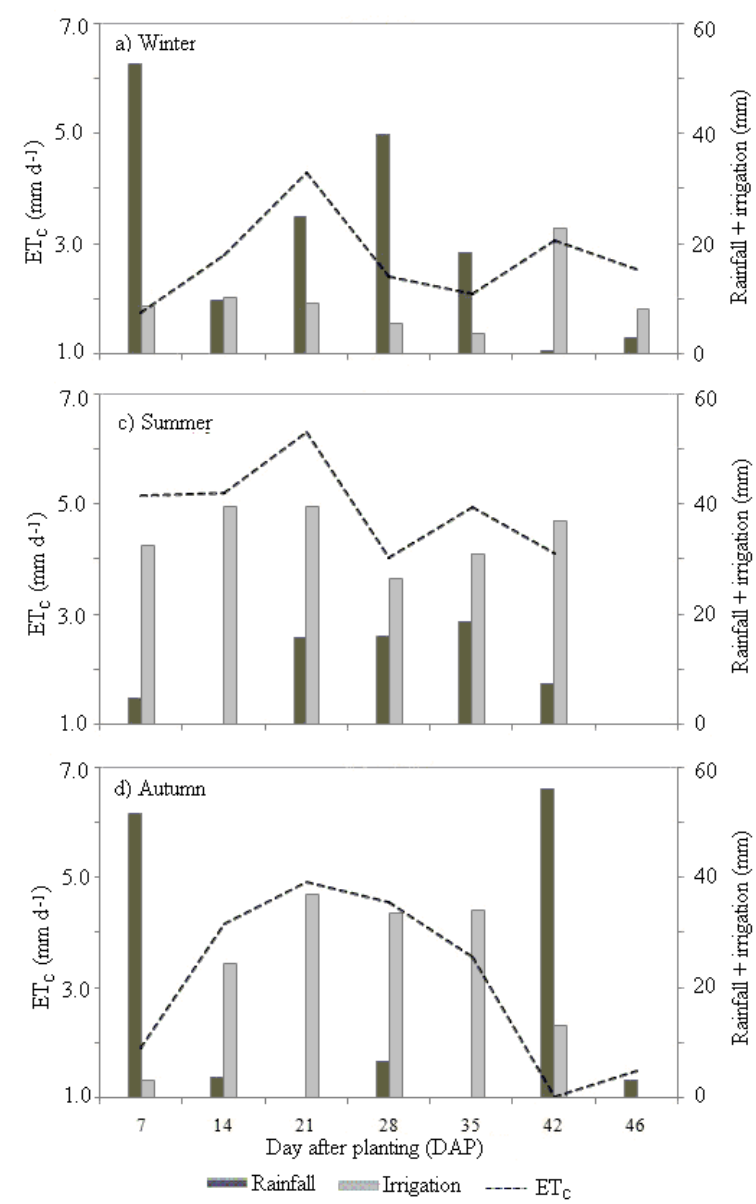

Figure 2 - Main daily evapotranspiration (ETC), rainfall and irrigation during: a) first experimental campaign (winter); B) second experimental campaign (summer); C) third experimental campaign (autumn).

Table 4 - Cumulativevalues of lettucecropevapotranspiration $\left(E T_{c}\right)$, reference evapotranspiration $\left(E_{0}\right)$ and water use efficiency (WUE)

\begin{tabular}{|c|c|c|c|c|c|}
\hline \multirow{2}{*}{$\begin{array}{l}\text { Growing } \\
\text { seasons }\end{array}$} & \multicolumn{2}{|c|}{ Evapotranspiration } & \multicolumn{3}{|c|}{ WUE (kg/ha mm) } \\
\hline & $\begin{array}{l}\text { Cumulative } \mathrm{ET}_{\mathrm{c}} \\
(\mathrm{mm})\end{array}$ & $\mathrm{ET}_{\mathrm{o}}(\mathrm{mm})$ & Looseleaf & Curly & Red \\
\hline Winter & 124.82 & 2.70 & 9.3 & 15.8 & 6.4 \\
\hline Summer & 208.08 & 4.62 & 8.9 & 6.4 & 3.6 \\
\hline Autumn & 142.65 & 3.07 & 15.5 & 28.5 & 19.0 \\
\hline Mean & 158.52 & 3.46 & 11.2 & 16.9 & 9.7 \\
\hline
\end{tabular}


Crop evapotranspiration was reduced by 59.9\% from summer to winter growing season and by $68.5 \%$ from summer to autumn growing season. Similar reduction was observed in $\mathrm{ET}_{\mathrm{o}}$. These changes resulted in lowest WUE during the summer growing season, which ranged from $3.6 \mathrm{~kg} / \mathrm{ha} \mathrm{mm}$ for the red cultivar to $8.9 \mathrm{~kg} / \mathrm{ha} \mathrm{mm}$ for the loose leaf cultivar. The lowest WUE occurred in the summer growing season for the three varieties because of the inherent highest values of crop evapotranspiration. The highest WUE was found during the autumn growing season for the curly cultivar $\left(285.9 \mathrm{~kg} \mathrm{ha}^{-1} \mathrm{~mm}^{-1}\right)$, while the lowest WUE rates were obtained during the winter and summer growing seasons for the red cultivar. A decrease in the yield and WUE of the three lettuce varieties was observed during the summer growing season as a result of both high air temperature and insolation and low rainfall. Abreu et al. (2014) also found a decrease in the yield of different lettuce varieties when grown in the summer season.

Lettuce crop coefficient can be determined with good precision $\left(r^{2}=0.95\right)$ as a function of the

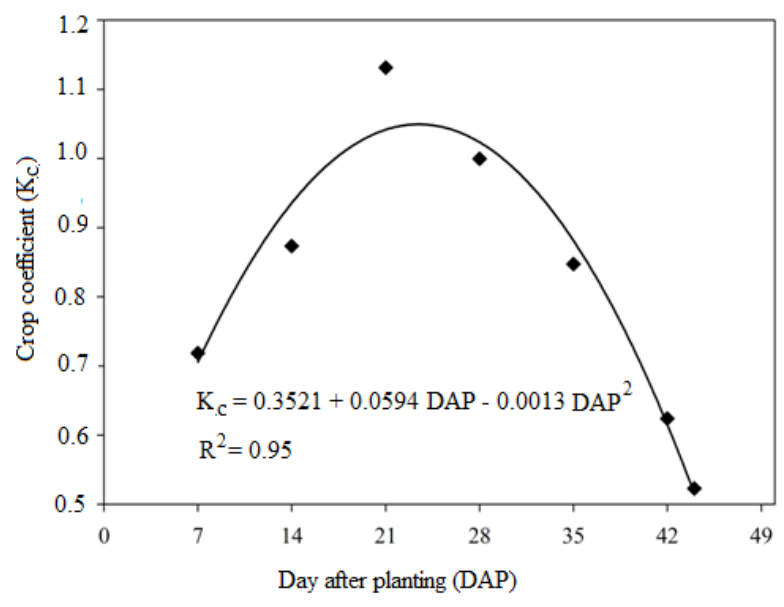

Figure 3-Crop coefficient curve of lettuce throughout development cycle under the climatic conditions of tropical region. number of days after transplanting (DAT), through the relationship: $\mathrm{K}_{\mathrm{c}}=0.3521+0.0594$ DAT -0.0013 $\mathrm{DAT}^{2}$ (Figure 3). Therefore, the observed temporal variation in $\mathrm{K}_{\mathrm{c}}$ is assumed to be a function of the DAP, with highly significant correlation coefficient. These results suggest that the equation reasonably describes the relationship between the crop coefficient and DAP.

The mean crop coefficient for lettuce growth in tropical region was 0.82 , while for the initial, middle and final stages are $0.80,1.07$ and 0.70 , respectively. These $K_{c}$ values were in a good agreement with the $K_{c}$ values given by Allen et al. (1998) during the initial, development and late growth stages of lettuce. On the other hand, studies conducted by Fernández-Pacheco et al. (2014) in Southeast Spain obtained $K_{c}$ values of $0.61,1.03$ and 0.98 in the initial, middle and final stages, respectively. The three lettuce varieties have different responses to the climatic conditions. The lowest yields were observed in the summer season, with values of 8.8 , 7.3 and $27.1 \mathrm{~kg} \mathrm{ha}^{-1}$, respectively for the looseleaf, curly and red lettuce varieties.

\section{CONCLUSIONS}

The mean crop coefficient of lettuce is 0.82 along the entire lettuce cycle, while in the initial, middle and final stages, the values were 0.80, 1.07 and 0.70, respectively. $\mathrm{ET}_{\mathrm{c}}$ values ranged from minimum of $2.74 \mathrm{~mm} /$ day with loose leaf cultivar to maximum value of $4.78 \mathrm{~mm} /$ day with red cultivar. The lettuce crop shows higher water demand in the summer period and the highest WUE was obtained during the autumn growing season with the curly cultivar $\left(285.9 \mathrm{~kg} \mathrm{ha}^{-1} \mathrm{~mm}^{-1}\right)$, while the lowest values were obtained during the winter and summer growing seasons with the red cultivar. The curly cultivar shows the highest yield, cultivated in the autumn growing season. The highest values in yield and WUE of lettuce during the autumn growing season were due to the favorable climatic conditions for crop development in tropical climate. 


\section{REFERENCES}

Abreu, M.M.; Neves, O. \& Marcelino, M. (2014) - Yield and uranium concentration in two lettuce (Lactuca sativa L.) varieties influenced by soil and irrigation water composition, and season growth. Journal of Geochemical Exploration, vol. 142, p. 43-48. https://doi.org/10.1016/j.gexplo.2014.01.018

Allen, R.G.; Pereira, L.S.; Raes, D. \& Smith, M. (1998) - Crop Evapotranspiration: Guidelines for computing crop water requirements. FAO Irrigation and drainage paper 56 . Rome, $300 \mathrm{p}$.

Allen, R.G.; Clemmens, A.J.; Burt, C.M.; Solomon, K. \& O'Halloran, T. (2005) - Prediction accuracy for projectwide evapo-transpiration using crop coefficients and reference evapotranspiration. Journal of Irrigation Drainage Engineering, vol. 131, n. 1, p. 1-24. https://doi.org/10.1061/(ASCE)0733-9437(2005)131:1(24)

Azevedo, P.V.; Silva, B.B. \& Silva, V.P.R. (2003) - Water requirements of irrigated mango orchards in northeast Brazil. Agricultural Water Management, vol. 58, n. 3, p. 241-254. http://dx.doi.org/10.1016/S0378-3774(02)00083-5

Azevedo, P.V.; Sousa, I.F.; Silva, B.B. \& Silva, V.P.R. (2006) - Water-use efficiency of dwarf-green coconut (Cocos nucifera L.) orchards in northeast Brazil. Agricultural Water Management, vol. 84, n. 3, p. 259-264. http://dx.doi.org/10.1016/j.agwat.2006.03.001

Bezerra Neto, B.; Porto, V.C.N.; Gomes, E.G.; Cecílio Filho, A.B. \& Moreira, J.N. (2012) - Assessment of agroeconomic indices in polycultures of lettuce, rocket and carrot through uni - and multivariate approaches in semi-arid Brazil. Ecological Indicators, vol. 14, n. 1, p.11-17. https://doi.org/10.1016/j. ecolind.2011.07.006

Candido, V.; D'Addabbo, T.; Miccolis, V. \& Castronuovo, D. (2011) - Weed control and yield response of soil solarization with different plastic films in lettuce. Scientia Horticulturae, vol. 130, n. 3, p. 491-497. https://doi. org/10.1016/j.scienta.2011.08.002

Cometti, N.N.; Martins, M.Q.; Bremenkamp, C.A. \& Nunes, J.A. (2011) - Nitrate concentration in lettuce leaves depending on photosynthetic photon flux and nitrate concentration in the nutrient solution. Horticultura Brasileira, vol. 29, n. 4, p. 548-553. http://dx.doi.org/10.1590/S0102-05362011000400018

Dufault, R. J.; Ward, B. \& Hassell, R. L. (2009) - Dynamic relationships between field temperatures and romaine lettuce yield and head quality. Scientia Horticulturae, vol. 120, n. 4, p. 452-459. https://doi.org/10.1016/j. scienta.2009.01.002

Ceuppens, S.; Hessel, C.T.; Rodrigues, R.Q.; Bartz, S.; Tondo, E.C. \& Uyttendaele, M. (2014) - Microbiological quality and safety assessment of lettuce production in Brazil. International Journal of Food Microbiology, vol. 181, p. 67-76. https://doi.org/10.1016/j.ijfoodmicro.2014.04.025

Fernández-Pacheco, D.G.; Escarabajal-Henarejos, D.; Ruiz-Canales, A.; Conesa, J. \& Molina-Martínez, J.M. (2014) - A digital image-processing-based method for determining the crop coefficient of lettuce crops in the southeast of Spain. Biosystems Engineering, vol. 117, p. 23-34. http://dx.doi.org/10.1016/j.biosystemseng.2013.07.014

Galieni, A.; Mattia, C.D.; Gregorio, M.D.; Speca, S.; Mastrocola, D.; Pisante, M. \& Stagnari, F. (2015) - Effects of nutrient deficiency and abiotic environmental stresses on yield, phenolic compounds and antiradical activity in lettuce (Lactuca sativa L.). Scientia Horticulturae, vol. 187, p. 93-101. https://doi.org/10.1016/j. scienta.2015.02.036

Ghiberto, P.J., Libardi, P.L.; Brito, A.S. \& Trivelin, P.C.O. (2011) - Components of the water balance in soil with sugarcane crops. Agricultural Water Management, vol. 102, n. 1, p. 1-7. https://doi.org/10.1016/j.agwat.2011.09.010

Groves, S.J.L. \& Rose, S.C.L. (2004) - Calibration equations for Diviner 2000 capacitance measurements of volumetric soil water content of six soils. Soil Use and Management, vol. 20, n. 1, p. 96-97. https://doi. org/10.1111/j.1475-2743.2004.tb00343.x

Hanson, B.R.; Schwankl, L.J.; Schulbach, K.F. \& Pettygrove, G.S. (1997) - A comparison of furrow, surface drip, and subsurface drip irrigation on lettuce yield and applied water. Agricultural Water Management, vol. 33, n. 2-3, p. 139-157. https://doi.org/10.1016/S0378-3774(96)01289-9

Křístková, E.; Doležalová, I.; Lebeda, A.; Vinter, V. \& Novotná, A. (2008) - Description of morphological characters of lettuce (Lactuca sativa L.) genetic resources. Horticultural Science, vol. 35, p. 113-129. https://doi. org/10.17221/4/2008-HORTSCI

Oliveira, M.; Usall, J.; Viñas, I.; Anguerra, M.; Gatius, F. \& Abadias, M. (2010) - Microbiological quality of fresh lettuce from organic and conventional production. Food Microbiology, vol. 27, n. 5, p. 679-684. https:// doi.org/10.1016/j.fm.2010.03.008 
Pereira, L.S.; Allen, R.G.; Smith, M. \& Raes, D. (2015) - Crop evapotranspiration estimation with FAO56: Past and future. Agricultural Water Management, vol. 147, p. 4-20. https://doi.org/10.1016/j.agwat.2014.07.031

Ryder, E.J. (1986) - Lettuce breeding. In: Bassett, M. (Ed.) - Breeding Vegetable Crops. AVI Publishing Co., Westport, p. 433-474.

Sala, F.C. \& Costa, C.P. (2012) - Retrospectiva e tendência da alfacicultura brasileira. Horticultura Brasileira, vol. 30, n. 2, p. 187-194. http://dx.doi.org/10.1590/S0102-05362012000200002

Serna, M.; Hernandez, F.; Coll, F. \& Amorosa, A. (2012) - Brassinosteroid analogues effect on yield and quality parameters of field-grown lettuce (Lactuca sativa L.). Scientia Horticulturae, vol. 143, p. 29-37. https:// doi.org/10.1016/j.scienta.2012.05.019

Silva, V.P.R. (2004) - On climate variability in Northeast of Brazil. Journal of Arid Environments, vol. 58, n. 4, p. 575-596. http://dx.doi.org/10.1016/j.jaridenv.2003.12.002

Silva, V.P.R.; Campos, J.H.B.C. \& Azevedo, P.V. (2009) - Water-use efficiency and evapotranspiration of mango orchard grown in northeastern region of Brazil. Scientia Horticulturae, vol. 102, n. 4, p. 467-472. https://doi.org/10.1016/j.scienta.2008.12.005

Silva, V.P.R.; Silva, B.B.; Albuquerque, W.G.; Borges, C.J.R.; Sousa, I.F. \& Dantas Neto, J. (2013) - Crop coefficient, water requirements, yield and water use efficiency of sugarcane growth in Brazil. Agricultural Water Management, vol.128, p. 102-109. http://dx.doi.org/10.1016/j.agwat.2013.06.007

Zhang, Y.; Kendy, E.; Qiang, Y.; Changming, L.; Yanjun, J. \& Hongyong, S. (2004) - Effect of soil water deficit on evapotranspiration, crop yield, and water use efficiency in the North China Plain. Agricultural Water Management, vol. 64, n. 2, p. 107-122. https://doi.org/10.1016/S0378-3774(03)00201-4

Zhou, Q.; Kang, S. Li, F. \& Zhang, L. (2008) - Comparison of dynamic and static APRI-models to simulate soil water dynamics in a vineyard over the growing season under alternate partial root-zone drip irrigation. Agricultural Water Management, vol. 95, n. 7, p. 767-775. https://doi.org/10.1016/j.agwat.2008.01.018 